\title{
Names on Dominica
}

\section{DOUGLAS TAYLOR}

\section{$\mathrm{T}$}

HE ISLAND OF DominiCA (pronounced with primary stress on the third syllable, and not to be confused with the Dominican Republic, Santo Domingo) was occupied successively by speakers of Arawak, Carib, French, and English dialects, all of which have left their mark in place-names, as well as in the names of local flora and fauna. African influence appears to have been minimal in this respect-partly, perhaps, because slaves were for the most part introduced from previously colonized, adjacent islands, rather than direct from Africa. Two languages are spoken today: English and French Creole or "patois," as it is called locally. The former, being the language of prestige, is usually employed by the more socioeconomically privileged minority; the latter by the peasant majority. However, members of the first class frequently resort to Creole in their more intimate relations, while many among even the poorest are often heard to address their young children in what they believe to be English, and to chide them for speaking "patois."

One curious result of this situation is that not only local fruits, trees, fishes, birds, etc., but also many places-probably most of those that have ever been recorded in writing-have two (or more) names, the one employed in Creole and the other in English speech. So, for example, Grande Anse or Portsmouth is the island's second largest town, Cachacrou or Scots Head a peninsula at its southwestern extremity, Cachibona or Clyde one of its many rivers, La Coudraie or Bath Estate one of its citrus plantations. In some cases a rival name has been defeated; La Dominique or Dominica (because Columbus first saw it on a Sunday) has quite superseded Uái-túkubuli (uái "old," túkubuli "her body") of the Indians, "Pointe Michel or Dalrymple's Point" of late-18th-century maps is now known only by the former designation, while another village, formerly known as La Soie, has now become Wesley to all 
except the local parish priest. Two more villages, whose names are both written Marigot, are distinguished in speech as [mærigot] (English pronunciation), and [maigo] (with French phonemes and loss of the "r.") The Indian place-name variously spelt as Coulihao, Coulihaut, Colihaut, Collihoe is now usually heard as indicated by this last, English spelling, although some of its older inhabitants still call it [kulíhao]. The best preserved names are, as a rule, those whose employment is most restricted or localized. So, in 1650 , Raymond Breton recorded the Island Carib name of a small stream in the northern district as Aóya (three syllables), probably meaning "guard"; and three hundred years later, when I crossed it, I was given the identical name by a peasant who lived nearby, and for whom it was "just a name." It was amusing to be told later by the local school-teacher that Aóya was "the patois corruption of Roullade, its real name."

It is unlikely that the etymology of all place-names employed in their language was clear to native speakers of Dominican Island Carib; and of these, reduced to a score of families by the beginning of last century, the last died about 1920 . Such of these names as can be interpreted today appear to be purely descriptive; so, for example, Cachacrou is certainly a French adaptation of Island Carib Kasákuru "(that which) is chewed or eroded (by the sea"; cf. asákura to "chew"), while Cachibona is most probably derived from cachibou, the local name of the plant Calathea lutea, which is a loan-word from Island Carib kasibu, with the same meaning and also "pointed" ( $k a$-attributive prefix plus isibu "face" or "point"), in reference to the shape of the leaves. Analogously, the name of the island's capital and of the river which runs through it, Roseau, is taken from the reed (French, roseau), Gynerium sagittatum, which grows profusely on the latter's banks. Clear also are the meanings of Balámuli "rolling (of a boat)," a river; Baraísiri "turning point" (bara "turn," isiri "nose" or "point"), a headland; Bátibu "at the hut" (báti "hut," -bu "at"), a hamlet; Búluku "plunging," a torrent; Burárati "notched" or "knobbly," a rocky cove; Butári cassava "griddle," piece of flat ground beside a river where once one stood; Isulukati "it has crayfish," a river also known as la rivière Cribiche and as Crayfish River; Kulúluti "collapsing," a steep ravine; Patáukati "flat," a provision ground, plantation; Séseti "flowing," a spring; Sibúli "boil," tumor, and species 
of fish, a fishing village; Tabátanakua "in between," a cove. Other Indian river or place-names whose etymology I will not attempt here include: Akayu, Aráturi, Fibáukati, Fráfrati, Kásayu, Kuánara, Kuária, Kuérek, Kusárakua, Kusarawa, Kusúna, Mágua, Pontompi, Sarísari, Síneku, Sípiyõ, Tumaka, Waiwai, Waiwáyao, Wáinika, Wakaresi, Wákamu, Wáraka, Wa(r)ísima, Wéti, not found on maps and here given in broadly phonetic transcription; and Barácoa, Báttali, Béllibou, Biámbouli, Boery, Boetica, Callibishi, Charounerouille, Colabone, Couáhari, Couánari, Cóuhara, Coulibístri, Coulouacoa, Craibo, Hiróula, Layou, Litachi, Macabou, Macouchery, Malalié, Mamamelou, Mamelabou, Mayambaccaly, Ouayanary, Ouycala, Ouyouhao, Pagoua (today pronounced Pegua) Romanbaty, Salibia, Tabieri, Tanama, Touloman, written in conventional (mostly French) spelling.

A certain number of Creole and (or) local English names for native flora and fauna have been borrowed from Island Carib. Examples from the former are Creole (French spelling): balisier Heliconia Bihai and H. Caribaea "wild plantain," from Island Carib baliri; calabouli and mibi, two species of liana or "bush cord"; cachibou (see above); l'arouman Ischnosiphon arouma, a tall plant whose stem is used for basketry, from Island Carib uarúma; latanier, a fan-palm, from Island Carib alátani; maho goujat or Marie goujat (sic!), a species of wild Passiflora, from Island Carib merékuia; mouben, Spondias lutea or "hog plum," a large forest tree, from Island Carib múbe; and z'icaque Chrysobalanus icaco or "fat pork," a wild shrub and fruit, from Island Carib $i k a ́ k u$ or hikáku. Among the latter are Creole (French spelling): balaou, coulirou, maouali, sibouli, and titiri, which are kinds of fish, and whose Island Carib form (apart from stress) has been preserved; cirique, a land crab; and héue-cong', conger-eel,- a curious compound of Island Carib héue "snake" and French congre "conger-eel"; the Cicérou, a large parrot, lamoussen (Island Carib alámuesei), a species of humming-bird, and courapiaou, another small bird; while gouti Dasyprocta agouti doubtless comes from Island Carib agúri. The mosquito larva or "wriggler" is still called (at least in some localities) by its Island Carib name, mabulésu (phonetic spelling). French colibri "humming-bird," Creole couliboui, species of humming-bird, as well as Creole courapiaou (see above) and Martinique coulivicou (yet another kind of bird) ap- 
pear to be related to Island Carib (k)ulibiniu, Lokono (Arawak) kudibiu, Kulina (Arawak) korobiriaru, all of which mean "bird" (generic); and if this should be so, one might hazard such a tentative reconstruction as *kurabiriharu "she has drunk medicine (or charm)." Creole vévéra, the name of a large black sea-worm, comes from Island Carib beléuera, which is a compound of béle "soft or glutinous" and éuera "tool or penis"; (an alternative Creole name-of French ancestry-is pipis neg' "Negro's penis"). Creole and local English manicou "opossum," from Island Carib maniku (with the same meaning), may be analysed into the privative prefix ma-, a root ani- "do" or "say," and a nominalizing suffix - $k u$, so that the name signifies, quite appropriately, "the quiet one." Finally, the burrowing flea (Pulex penetrans) known as chigoe (British spelling )or jigger (American spelling) to English speakers, and as chique to French and Creole speakers, takes both of these names from Island Carib siko [šíkë] (with the same meaning), which is obviously related to asika "to dig."

Writing in the mid-seventeenth century, Raymond Breton mentions a Dominican chief named Ukale "stick insect," and a woman who named her baby girl Uliémbana "Seaside-grape leaf" (Coccoloba uvifera); it seems that Island Carib personal names were always descriptive or reminiscent. Today, Dominica's few remaining Indians bear French or English 'Christian' names; but there is still a man nicknamed Katáru "turtle," and a woman commonly called Kalemía, which is (or was) the name of a species of bird.

Place-names of French ancestry fall into two main groups: those which designate or once designated an "estate" (English) or "habitation" (French)-that is, a plantation; and the others. The first usually commemorate the first owner's family name, while the second are for the most part descriptive of some natural feature. So Auber, Dauchamps, Dilon, Dublanc, La Coudraie (despite its also meaning "hazelnut grove"), Picard, Rosalie, and St. Aromant are still plantations bearing the names of their first, long-dead owners; while Laudat, Loubière, and Pichelin are villages that grew up about the now defunct estates of MM. Laudat, de l'Oubière, and Jean-Baptiste Pichelin. Indeed, nearly all the present inhabitants of Laudat claim descent from that enterprising gentleman, who is said to have arrived from Martinique alone and to have settled on the high plateau, overlooking both Caribbean and Atlantic, where 
the village named for him now stands. As might be expected, both the villages called Souffrière are situated near volcanic sulphursprings, Grand Fond nestles in a deep hollow, Grande Anse overlooks a landlocked bay, Dos d'Ane bestrides a ridge, and La Plaine is built on a comparatively flat coastal stretch. Marigot is the French name for a tropical river-mouth that loses itself underground, or becomes inundated by the sea. Vieille Case is built upon or near the site of the oldest known Carib settlement in the island; though whether the name refers to this fact or not I cannot say. The name of Roseau, the capital, has already been explained; and the village name, Mahaut, refers likewise to several species of trees so called (maho), whose fibrous bark is used as a natural rope. Exceptionally, Massacre recalls the one-time slaughter of an Indian community there by the English.

Mountains are named for their prevailing color (Morne Jaune, Morne Vert), for the birds that frequent or frequented them (Morne Diablotin for a probably extinct species of petrel, Morne aux Frégates for the frigate-bird), for a species of tree common on their slopes (Morne Bois Diable-a Licania), a nationality (Morne Anglais, Morne Espagnol, Morne Lorrain), characteristic appearance (Morne Canot, Morne Brulé, Trois Pitons), or appurtenance (Morne la Fontaine). The same is true, by and large, of other natural features of the landscape; so, Pointe Ronde (from its shape), Pointe Crabier (for the crabier or gaulin bird, a large species of heron), Pointe Caraibe and Pointe Mulâtre (for some early inhabitants), La Rivière Claire (for its good water), Dlo Gommier (Creole dlo or glo "water," from French de l'eau), Dlo Manioc, Dlo Morne Lorrain, which take their names from the vegetation lining their banks and from the mountain source respectively.

Other names are less clear. A rocky pinnacle overhanging the sea may owe its name, La Sorcière, to a tradition according to which the Caribs used to cast witches to their death from its summit. The entrance to a large cave in the cliffs, said to have been once used by smugglers, is called the Gueule du Lion. Such names as La Rivière de l'Or and La Rivière des Belles Filles may refer to onetime fact or fancy; while Perte de Temps and recently named Fan $\mathrm{Cu}$ (Creole, from French fendre cul) refer to unfortunate mishaps, as does also Cavalier, so named since a drunken horseman and his mount ended their days by falling over the precipice there. Perhaps 
only one who has climbed it can fully appreciate the name of Morne Paix Bouche (Mount Hush Mouth).

An adequate treatment of the Creole nomenclature for local species of flora and fauna would require a monograph in itself; although English equivalents exist, for the most part, only for cultivated species and for those few that are wild which have some utility or other interest to the white man. It must suffice here to mention some of the characteristics of this nomenclature. So, a botanist might be deceived into believing that Maho doux, Mahot noir, Maho piment, Maho cochon, Maho cousin, and Maho figue indicated something like the scientific division by genus and species. However, the "genus" Maho denotes only that strong fibres used as rope are furnished by all these plants, some of which are forest trees, some mere shrubs, and one (Maho figue) a relative of the banana-the imported Musa textilis or Manilla hemp. Analogously, the various trees and plants called Savonette all provide a substitute for soap. On the other hand, Creole often ignores what to us are obvious family likenesses; Gaoula, Glouglou, Grigri, Latanier, Palmis' (French Palmiste), Yanga, and Yattahou are all what we should call palms of various sorts, but the concept palm cannot be expressed in Creole. Similarly, the couresse and the couleuvre are two species of grass-snake, the tête-chien is a boa, while serpent is the name of the venomous fer-de-lance; but there is no word in Creole for snake.

Some trees, such as Bálata and Acoúquoi, have kept their native Indian names; many have been named after European species to which some real or fancied likeness has been seen by the early French colonists,--so noyer, noyau, porier (poirier), z'olivier, z'abricot; others, such as bois d'ail, laurier caca, laurier poivre, laurier rose, take their names from a characteristic smell of their wood. Similarly with much of the fauna; the names of the zandoli and kulélé lizards are corruptions of Island Carib anáuli and kuhílele; the grive, merle, perdrix, and ramier are assimilated to their European namesakes; while the Hercules beetle (Dynastes Hercules) is called scieur de long "pit-sawyer" because of the noise produced when it "saws" off twigs with its long strong mandibles by swinging around and around them. Another noisy insect is called (phonetic) masoče "blacksmith," and two more krak-krak and zing-zing, which would seem to be onomatopoeic. Sometimes an identical species is 
known by different names in different localities of the island; so mang' rouge, lagali, cacquelin are different names for a parasitic creeper that strangles trees; while tak-tak, flamand, (a)rada are different names for the same big black ant.

The names bestowed upon their plantations by English and other recent settlers usually hark back to "the old country," or else are merely pretentious: Bath, Belfast, Blenheim, Castle Bruce, Castle Comfort, Copt Hall, Hampstead, Lisdara, Londonderry, Melville Hall, Moore Park, Ryegate, South Chiltern, Trafalgar. One small farm has recently had its "official" name changed from Perrot (the older form of French Pierrot) to New Florida, while D'l'eau Morne Lorrain has been rebaptized Norway by a road-gang working in the vicinity.

Because of the smallness of its size ( $308 \mathrm{sq} . \mathrm{mi}$.) and the heterogeneity of its biota (including man), Dominica offers an exceptional opportunity to the onomatologist at the present time. Here it has not been possible to give more than a small sampling of the names to be found there; many of them-and among the most interesting - known only to those who have spent their lives in the immediate neighborhood of the features they designate, and never recorded. But the island is not so remote as to have been left untouched by the general world unrest; the younger generation cares little for the old rural life and interests, and is crowding into the town or emigrating; and it seems inevitable that many of the old names of "unimportant" places and biota will soon be forgotten.

$$
\diamond \diamond \diamond
$$

Muscles and Names-The press of the Michigan State College, a library member of the $A N S$ recently published a monograph entitled, $A$ Cross Sectional Muscle Nomenclature of the Beef Carcass, edited by L. J. Bratzler. 